INTERNATIONAL JOURNAL OF MULTIDiscipLINARY RESEARCH AND ANALYSis

ISSN(print): 2643-9840, ISSN(online): 2643-9875

Volume 04 Issue 04 April 2021

DOI: 10.47191/ijmra/v4-i4-18, Impact Factor: 6.072

Page No.- $477-483$

\title{
The Impact of Remittances on the Skipped Generation Households in Vietnam
}

\author{
Hue Thi Hoang ${ }^{1}$, Hien Thi Thao Dinh ${ }^{2}$, Hang Thi Thuy Nguyen ${ }^{3}$, Hien Thu Phung ${ }^{4}$, Trang Thi Thu Pham ${ }^{5}$ \\ 1,4,5Lecture, Department of Human Resources Economics and Management, National Economics University, Hanoi, Vietnam \\ ${ }^{2,3}$ Student, Department of Human Resources Economics and Management, National Economics University, Hanoi, Vietnam
}

\begin{abstract}
Using the data from Vietnam Living Standards Survey (VHLSS) 2014, 2016, 2018 of the General Statistics Office of Vietnam, we do research about the impact of remittances on skipped generation households. Through testing with the fixed effects model (FEM) and the random impact model (REM), we found that the remittances received by these households have positive impacts on children's education and children's health. Specifically, when increasing $1 \%$ of remittances, the probability of children going to school and entering the right age increases by 1,108 and 1,112 times; the opposite trend happened with the child malnutrition. Moreover, the degree of influence is also different for each form of remittance.
\end{abstract}

KEYWORDS: remittances, skipped generation households, children's education, children's health

\section{INTRODUCTION}

In recent years, along with the trend of strong global economic liberalization, the labor export activity has become ever more popular in all countries of the world. With the policy of easing remittance management, the amount of remittances sent to developing countries has significantly increased and accounts for a large proportion in the economy. According to statistics, in 2016, 537 billion USD of remittances were received globally, accounting for about $0.72 \%$ of world GDP. Ratha et al (2016) shows that remittances are the second most important source of international capital for developing countries, only behind Foreign Direct Investment (FDI) and always superior than the Official Development Assistance (ODA). From many other perspectives, remittances flow affects both the household level and the whole economy; influence macroeconomic management, labor force participation, education and health outcomes, income distribution and household expenditure patterns (Trang and Plaza, 2006).

In Vietnam, both internal and international migration have been increasing rapidly. According to the Population and Housing Census (2009), about 6.5\% of the population over 5 years old had a change of residence between 2004-2009. The proportion of urban population increased from about 24\% in 2001 to $30 \%$ in 2009 (Nguyen, 2012). This has resulted in a significant increase in international and domestic remittances, estimated at nearly 17 billion USD, ranking ninth in the world (World Bank, 2019). Therefore, the urgent issue is how to attract remittances, while controlling the amount of international and domestic remittances towards the most comprehensive socio-economic development goal. Especially, at a micro level, one of the most affected subjects of remittances is households (Trang, 2006).

\section{OVERVIEW AND RESEARCH METHODS}

\subsection{Concepts}

\subsubsection{Remittances}

Remittances play an important role in the economic development of remittance areas because of their significant contribution to finance, typically in many developing countries (Todaro \& Smith, 2012). However, most studies only focus heavily on international remittances due to the lack of available data on domestic remittances; Although migration and domestic remittances account for a larger share of total migration and remittances (Castaldo et al., 2012). Besides, each researcher has different views, so the concept of remittances is not really clear and unified.

With international remittances, Puri \& Ritzema (1999) defined this as the income of foreigners sent home. With that same view, in many other later studies, international remittances have been broadly defined as cross-border remittances sent by overseas migrants to households in their home countries. , mainly to meet the family's financial needs. Specifically, in the IMF's 


\section{The Impact of Remittances on the Skipped Generation Households in Vietnam}

Handbook of Balance of Payments (BOPM5), international remittances are remittances made by migrants; these people work in new economies for at least a year and send money back to their home country (Balance of payments Handbook, 2006).

With domestic remittances, this concept in the studies is not really specific and clear due to the different socio-economic characteristics in each country, leading to the difference in domestic remittances. However, the term domestic remittances has been mentioned in a few studies on the Chinese migration system. According to the International Organization for Migration (IOM, 2006), domestic remittances are part of a strategy to diversify rural livelihoods. For households in rural China, their source of income comes from agricultural and non-agricultural activities. Therefore, when the local economy does not satisfy non-farm jobs, family members will move to major cities in the country to work. At that time, the source of money transfers from internal migrants to the households in their home country was remittances (Hare, 1999). In many studies it has been found that the total amount of domestic remittances sometimes exceeds the amount of international remittances (Castaldo, 2012).

Thus, most previous studies have shown that remittances play an important role in promoting and developing the socioeconomic of each country. Therefore, to match the practical situation in Vietnam, the research team will approach remittances in both aspects: international remittances and domestic remittances.

\subsubsection{Skipped Generation Households}

Skipped Generation Households include children and their grandparents - who are responsible for taking care of children on behalf of their parents due to migration for the purpose of finding work, improving income (Ingersoll - Dayton \& plus, 2018). More specifically, Casper \& Bryson (1998) restricts the number of children in the concept of the remaining generation to children under the age of 18 .

At the same time, Fuller - Thompson (2005) defines Households that can be kept by relatives as families with only grandparents and grandchildren living together, without the presence of parents, uncles or any relatives. , which relatives. Many studies show that unemployment and low average income are the main reasons why many parents leave, handing their children to their grandparents to foster in order to find better jobs with the aim of improving family life. family (Kelly et al., 1997; Bryson \& Casper, 1999; Minkler \& Odierna, 2001; Bramlett \& Blumberg, 2007).

\subsection{The Impact of Remittances on the Skipped Generation Households}

Since Backer's first work (1982), the allocation of time for work and rest in the household has received considerable interest in economics. Backer found the impact of remittances on consumer markets in developing countries showing conflicting results. On the one hand, remittances relax household-level economic restrictions, creating favorable conditions for new business activities, leading to increased workforce participation. On the other hand, remittances can reduce the supply of labor by increasing the income of household members through receiving remittances. However, research on these issues has yet to give a thorough explanation, especially in studying the effects of remittances on the generation of people staying behind, particularly children and the elderly in the household. .

Taylor (1992) used data collected in the 1983 and 1989 household living standards surveys on households and farms in the state of Michoacan, Mexico, and found that remittances alleviate household problems. liquidity, stabilizing consumption and investment in production. Thereby, remittances have a positive impact on reducing the number of child labor and restricting children entering the labor market. Then, Guarcello (2003) shows that through increasing income and consumption, remittances can improve children's health, as well as education. By 2006, Mansuri (2006) found that remittances sent by temporary migrants had a positive impact on children's school attendance, especially for girls. Experimenting with a Stackelberg model using data from the Republic of the Congo, the author points out that family members receiving remittances will express gratitude by choosing to invest more in children's education. Because this will reduce the burden on the migrants when they return. The results also confirm that for rural girls, remittances are statistically significant and have a positive impact on school attendance.

Similarly, Milgan \& Bohara (2007) analyzed the impact of increases in income from remittances on academic achievement (level of education) and number of child labor (number of hours children worked) using procedures. Heckman's two steps for Nepal. The model estimates the impact of different types of income on child labor and education using data from the $2003 \mathrm{Nepal}$ Living Standards Survey. The authors report on remittances from national sources. Health care sector positively and significantly contributes to child welfare in Nepal. If remittances are considered as an additional source of household income, when the income increases, parents do not need to let their children participate in production or business activities or participate in the market. labor school.

However, Taylor \& Lopez Feldman (2007) reported that remittances may not lead to an increase in household income and consumption as they prevent them from earning higher income through labor-intensive activities. In other special cases, remittances can also pose a number of risk problems if remittance recipients lose motivation to work through income and replacement effects (Farrington \& Slater, 2006; Sahn; \& Alderman, 1996). The income effect lessens household budget constraints 


\section{The Impact of Remittances on the Skipped Generation Households in Vietnam}

and increases salary retention for remaining members; while the substitution effect creates an incentive to cut down the labor supply to continue receiving remittances (Killingsworth, 1983; Amuedo-Dorantes, 2014). In addition, when the number of people migrating abroad is large, it means that the proportion of adults staying at home will decrease. This can have a major impact on the care and education of children. Without a caregiver, children may have poorer education and health and have to do more housework (Kandel \& Kao, 2001; McKenzie \& Rapoport, 2006). Research by Giannelli and Mangiavacchi (2010) in Albania shows that parental migration can have a negative impact on long-term school attendance, mainly due to a lack of parental interest in children. was left behind. In addition, as mentioned, if remittances and migration do not lead to an increase in income, the positive effects of remittances and migration on the education of children through the income channel will be negligible (Azam \& Flore, 2006).

Thus, most of the research around this topic only gives the relationship between remittances and the generation of people staying in each separate aspect and not total. This leads to a gap in specifically identifying the positive and negative effects of remittances on the remaining generation, in particular the elderly and children in the household. From there, the research team found that, to consider most clearly about this relationship, it is necessary to clearly point out the impact of remittances on the following aspects: health, education and employment of the living generation. back in this relationship. However, in the framework of this article, we only consider the effects of remittances on the health and education of children in the skipped generation households.

\section{RESEARCH METHODS}

The main research method used in the model is econometric regression with the general model as follows:

$$
Y=\beta_{0}+\beta_{1} \ln (X)_{i t}+\beta_{2} X_{i t}+\beta_{3} D_{i t}+\beta_{4} G_{t}+\varepsilon_{i t}
$$

In which:

$Y$ : the dependent variable (including quantitative variables and dummy variables)

In $\left(X_{i t}\right)$ : the amount of domestic remittances, international remittances and domestic remittances received over the years

$X_{i t}$ : the proportion of remittances in income and expenditure

Dit: a dummy variable to receive remittances or not ?

$\mathrm{G}_{\mathrm{t}}$ : the dummy variable of years; $\varepsilon_{\mathrm{it}}$ are unobserved variables.

Since the dependent variables include both quantitative and dummy variables, the authors consider using different models suitable for each type of variable. According to Gujarati (2012), the Pooled OLS model is also known as the constant coefficient model and they are assuming constant time coefficients and cross observations, which ignores the dual nature of the array data. Therefore, in this study, we only focus on evaluating the values of the fixed effects model (FEM) and random impact model (REM) for the non-dummy dependent variable through the Hausman test ( Durbin-Wu-Hausman test, 1978). The test results show that Prob> chi2 is greater than 0.05, so REM model selection is appropriate. The group also tested LM-Breusch Pagan and as a result, there is no variance of variance in the model. Models with dependent variables are binary should use either logit or probit (Gujarati, 2012). Since both models give similar results and the choice between these two models depends on the available software and which one is more easily explained, the team chose to use the logit model in the study. this.

\section{DATA ANALYSIS}

\subsection{Data description}

This study uses data from the Vietnam Household Living Standards Survey (VHLSS) 2014, 2016 and 2018. VHLSS surveys are conducted by the General Statistics Office of Vietnam (GSO) with support from the World Bank. The VHLSS surveys were conducted on selected households and communes in 63 provinces. Household data includes some characteristics of the household demographic, income, and expenditure; each family member's health, fixed assets, education, technical qualifications, and participation in social assistance programs. Commune data includes some general information on demographics, ethnicity, economic status, and health status of the people.

According to statistics, in each VHLSS survey it is possible to collect information from more than 9,000 households. This data set represents the total number of households living in all 63 provinces in Vietnam. In this study, the group used a sample of 5,136 households filtered from VHLSS data in 03 years 2014, 2016, 2018 with criteria on household characteristics relevant to the topic. 
The Impact of Remittances on the Skipped Generation Households in Vietnam

Table 1: Variables Used in the Study

\begin{tabular}{|c|c|c|}
\hline Variables & Components & Explanation \\
\hline \multirow[t]{6}{*}{ 1. Remittance } & $\begin{array}{l}\text { R1: A binary ( } 0 \text { or } 1 \text { dummy) variable } \\
\text { whether remittances are received }\end{array}$ & $\begin{array}{l}\text { 1: Households receive remittances } \\
0: \text { Households do not receive remittances }\end{array}$ \\
\hline & R2: The value of remittances & $\ln (R 2)$ \\
\hline & R3: International remittances & $\ln (\mathrm{R} 3)$ \\
\hline & R4: Internal remittances & $\ln (\mathrm{R} 4)$ \\
\hline & $\begin{array}{l}\text { R5: Ratio of remittances to household } \\
\text { income }\end{array}$ & $\begin{array}{l}\text { Total of remittances / Income of } \\
\text { household*100 }\end{array}$ \\
\hline & $\begin{array}{l}\text { R6: Ratio of remittances to household } \\
\text { expenditures }\end{array}$ & $\begin{array}{l}\text { Total of remittances / Expenditures of } \\
\text { household*100 }\end{array}$ \\
\hline \multirow[t]{4}{*}{$\begin{array}{l}2 . \quad \text { Skipped } \\
\text { generation } \\
\text { household }\end{array}$} & $\begin{array}{l}\text { S1: A binary ( } 0 \text { or } 1 \text { dummy) variable } \\
\text { whether children attend school }\end{array}$ & $\begin{array}{l}0: \text { At least a child in the household does not } \\
\text { attend school } \\
1: \text { The total children in the household attend } \\
\text { school }\end{array}$ \\
\hline & $\begin{array}{l}\text { S2: A binary ( } 0 \text { or } 1 \text { dummy) variable } \\
\text { whether children's school attendance at } \\
\text { the right age }\end{array}$ & $\begin{array}{l}0: \text { At least a child in the household is enrolled } \\
\text { at the wrong age } \\
\text { 1: All children in the household are enrolled } \\
\text { at the right age }\end{array}$ \\
\hline & $\begin{array}{l}\text { S3: The proportion of children } \\
\text { participating in health insurance in the } \\
\text { household }\end{array}$ & $\begin{array}{l}\text { The number of children participating in } \\
\text { health insurance/ The number of children in } \\
\text { the household }\end{array}$ \\
\hline & S4: Are children malnourished or not? & $\begin{array}{l}\text { 1: Children are malnourished } \\
0: \text { Children are not malnourished }\end{array}$ \\
\hline
\end{tabular}

Source: Summary of the Authors

\subsection{Effects of Remittances on the Skipped generation households}

Regarding child education, whether or not a household receives remittances, the total amount of remittances, international remittances, domestic remittances and the proportion of remittances in income all affect the education of children in the same direction. Specifically, households receiving remittances are 1.26 times more likely to go to school and 1.34 times higher than that of households that do not receive remittances. In addition, when the total amount of remittances increases by $1 \%$, the probability of children going to school and enrolling at the right age will increase by 1,108 and 1,112 respectively. For households receiving international remittances, the impact on children's education is not so obvious, but the probability of children going to school will be 1.4 times higher than that of children not attending school. In contrast, the amount of domestic remittances has a marked effect on the education of children. The probability of children going to school and enrolling will increase by 0.102 and 0.117 for those receiving domestic remittances. The proportion of remittances in income also increases the probability of children attending school 1,0069 times higher than children not attending school.

In terms of health, whether or not a household receives remittances does not have a significant effect on the child's health. However, the amount of remittances received by the household will contribute to a $0.0038 \%$ increase in the proportion of children participating in health insurance and a decrease in the probability of the child being malnourished. Similarly, when the 


\section{The Impact of Remittances on the Skipped Generation Households in Vietnam}

number of international remittances increased by $1 \%$, this figure increased to $0.0149 \%$ for the proportion of children enrolled in health insurance and child malnutrition was not significantly affected. Domestic remittances not only have a clear impact on children's education but also on children's health. Domestic remittances increased by $1 \%$, the rate of children participating in health insurance increased by $0.004 \%$ and the probability of children suffering from malnutrition decreased. In addition, the proportion of remittances in household income and expenditure has a negative impact on the proportion of children participating in health insurance, but has a positive impact on the child malnutrition problem. The probability of children suffering from malnutrition decreases by 0,997 and 0.999 times as the remittance rate in income and expenditure increases.

Table 2: Regression results

\begin{tabular}{|c|c|c|c|c|}
\hline Variables & $\begin{array}{l}\text { (1) Whether } \\
\text { children go } \\
\text { to school or } \\
\text { not? }\end{array}$ & $\begin{array}{l}\text { (2) Children's } \\
\text { school } \\
\text { attendance at } \\
\text { the right age }\end{array}$ & $\begin{array}{l}\text { (3) The } \\
\text { proportion of } \\
\text { children } \\
\text { participating in } \\
\text { health insurance } \\
\text { in the household }\end{array}$ & $\begin{array}{l}\text { (4) Are children } \\
\text { malnourished or } \\
\text { not? }\end{array}$ \\
\hline \multirow[t]{2}{*}{$\begin{array}{l}\text { Does the household receive } \\
\text { remittances? }\end{array}$} & $1.265^{* *}$ & $1.341^{* * *}$ & -0.103 & 1.021 \\
\hline & $(0.133)$ & $(0.091)$ & $(0.563)$ & $(0.053)$ \\
\hline \multirow[t]{2}{*}{ The total value of remittances } & $1.108 * * *$ & $1.113^{* * *}$ & $0.381 * * *$ & $0.908 * * *$ \\
\hline & $(0.034)$ & $(0.022)$ & $(0.143)$ & $(0.012)$ \\
\hline \multirow[t]{2}{*}{ International remittances } & $1.407^{*}$ & 1.078 & $1.495 * *$ & 1.004 \\
\hline & $(0.291)$ & $(0.124)$ & (0.649) & $(0.08)$ \\
\hline \multirow[t]{2}{*}{ Internal remittances } & $1.102 * * *$ & $1.117^{* * *}$ & $0.405^{* * *}$ & $0.908 * * *$ \\
\hline & $(0.035)$ & $(0.022)$ & $(0.649)$ & $(0.012)$ \\
\hline \multirow[t]{2}{*}{$\begin{array}{l}\text { Ratio of remittances to } \\
\text { household income }\end{array}$} & $1.007^{*}$ & 0.999 & -0.002 & $0.997 * *$ \\
\hline & $(0.0037)$ & $(0.001)$ & $(0.015)$ & $(0.0011)$ \\
\hline \multirow[t]{2}{*}{$\begin{array}{l}\text { Ratio of remittances to } \\
\text { household expenditures }\end{array}$} & 1.00005 & 0.999 & -0.002 & $0.999 * *$ \\
\hline & $(0.0008)$ & $(0.0004)$ & $(0.0032)$ & $(0.0028)$ \\
\hline Constant & 0.0001 & 1.519 & $38.153^{* *}$ & 0.578 \\
\hline Observations & 17,400 & 17,400 & 17,400 & 17,400 \\
\hline Pseudo R2/R-squared overall & 0.3145 & 0.0395 & 0.0896 & 0.0246 \\
\hline \multicolumn{5}{|l|}{$\begin{array}{l}\text { Standard errors in parentheses } \\
* \mathrm{p}<0.1, * * \mathrm{p} 0<.05, * * * \mathrm{p}<0.01\end{array}$} \\
\hline
\end{tabular}

Source: Authors' Estimation from the VHLSS 2014, 2016, 2018

\section{CONCLUSIONS}

Significant increase in all countries, especially developing countries. In the world, there are many studies on the influence of this family structure system, however, the number of studies in Vietnam remains limited. Therefore, we consider the effect of remittances on child's education and child's health. By using VHLSS data 2014, 2016, 2018 with the support of STATA software, the results show that remittances have positive impacts on the health and education of children. The analysis of the difference between the effects of domestic and international remittances, has highlighted the greater importance of domestic remittances to child's education and child's health. Specifically, the rate of domestic remittances that contributes to the increase in school 


\section{The Impact of Remittances on the Skipped Generation Households in Vietnam}

enrollment and enrollment rates of children is 0.10 and 0.177 , respectively. Similarly, transferring money domestically reduces the rate of malnourished children by 0.098 . The study also shows that, in the skipped generation households, although the Ratio of remittances in total income and the Ratio of remittances on household's expenditures has impacts on children's health and education, they are not clear and significant. The findings in this study may suggest some policy implications for the issue of labor and employment in Vietnam, aiming to ensure a stable life, satisfying basic needs for people. people, especially vulnerable groups such as the generation of people left behind.

\section{REFERENCES}

1) Askarov, Z., \& Doucouliagos, H. (2020). A meta-analysis of the effects of remittances on household education expenditure. World Development, 129, 104860.

2) Adams Jr, R. H., \& Cuecuecha, A. (2010). Remittances, household expenditure and investment in Guatemala. World Development, 38(11), 1626-1641.

3) Bansak, C., \& Chezum, B. (2009). How do remittances affect human capital formation of school-age boys and girls?. American Economic Review, 99(2), 145-48.

4) Karki Nepal, A. (2016). The impact of international remittances on child outcomes and household expenditures in Nepal. The Journal of Development Studies, 52(6), 838-853.

5) Azizi, S. (2018). The impacts of workers' remittances on human capital and labor supply in developing countries. Economic Modelling, 75, 377-396.

6) Amuedo-Dorantes, C., \& Pozo, S. (2006). Remittance receipt and business ownership in the Dominican Republic. World Economy, 29(7), 939-956.

7) De, P. K., \& Ratha, D. (2012). Impact of remittances on household income, asset and human capital: Evidence from Sri Lanka. Migration and Development, 1(1), 163-179.

8) Amuedo-Dorantes, C., \& Pozo, S. (2010). Accounting for remittance and migration effects on children's schooling. World development, 38(12), 1747-1759.

9) Pickbourn, L. (2016). Remittances and household expenditures on education in Ghana's northern region: why gender matters. Feminist Economics, 22(3), 74-100.

10) Alcaraz, C., Chiquiar, D., \& Salcedo, A. (2012). Remittances, schooling, and child labor in Mexico. Journal of Development Economics, 97(1), 156-165.

11) Edmonds, E. V., \& Pavcnik, N. (2005). Child labor in the global economy. Journal of Economic Perspectives, 19(1), $199-220$.

12) Nguyen, C. V., \& Nguyen, H. Q. (2015). Do internal and international remittances matter to health, education and labor of children and adolescents? The case of Vietnam. Children and Youth Services Review, 58, 28-34.

13) Yang, D. (2003). Remittances and Human Capital Investment: Child Schooling and Child Labor in the Origin Households of Overseas Filipino Workers. Unpublished manuscript Gerald R. Ford School of Public Policy and Department of Economics. Ann Arbor: University of Michigan.

14) Mansuri, G. (2006). Migration, school attainment, and child labor: evidence from rural Pakistan. The World Bank.

15) Milligan, M., \& Bohara, A. (2007). The effect of remittances on child labor and child education in Nepal.

16) Acosta, P. (2006). Labor supply, school attendance, and remittances from international migration: the case of El Salvador. World Bank Policy Research Working Paper, (3903).

17) Cuadros-Menaca, A., \& Gaduh, A. (2020). Remittances, child labor, and schooling: Evidence from Colombia. Economic Development and Cultural Change, 68(4), 1257-1293.

18) Nguyen, T., \& Purnamasari, R. (2011). Impacts of international migration and remittances on child outcomes and labor supply in Indonesia: How does gender matter?. The World Bank.

19) Calero, C., Bedi, A. S., \& Sparrow, R. (2009). Remittances, liquidity constraints and human capital investments in Ecuador. World Development, 37(6), 1143-1154.

20) Sasin, M. J., \& McKenzie, D. (2007). Migration, remittances, poverty, and human capital: conceptual and empirical challenges.

21) Borraz, F. (2005). Assessing the impact of remittances on schooling: The Mexican experience. Global Economy Journal, 5(1), 1850033.

22) Nguyen, C., \& Nguyen, H. (2013). Do Internal and International Remittances Matter to Health, Education and Labor of Children? The Case of Vietnam. 


\section{The Impact of Remittances on the Skipped Generation Households in Vietnam}

23) Hu, F. (2012). Migration, remittances, and children's high school attendance: The case of rural China. International Journal of Educational Development, 32(3), 401-411.

24) Mueller, V., \& Shariff, A. (2011). Preliminary evidence on internal migration, remittances, and teen schooling in India. Contemporary Economic Policy, 29(2), 207-217.

25) Khan, S. U., \& Khan, M. J. (2016). The impact of remittances on child education in Pakistan.

26) Antén, J. I. (2010). The impact of remittances on nutritional status of children in Ecuador. International migration review, 44(2), 269-299.

27) Salas, V. B. (2014). International remittances and human capital formation. World development, 59, $224-237$.

28) Amuedo-Dorantes, C., \& Pozo, S. (2010). Accounting for remittance and migration effects on children's schooling. World development, 38(12), 1747-1759.

29) Kapur, D. (2005). Remittances: the new development mantra?. Remittances: Development impact and future prospects, 2(1), 331-360.

30) Ingersoll-Dayton, B., Tangchonlatip, K., Punpuing, S., \& Yakas, L. (2018). Relationships between grandchildren and grandparents in skipped generation families in Thailand. Journal of Intergenerational Relationships, 16(3), $256-274$.

31) Wen, M., Ren, Q., Korinek, K., \& Trinh, H. N. (2019). Living in skipped generation households and happiness among middleaged and older grandparents in China. Social science research, 80, 145-155.

32) Ingersoll-Dayton, B., Tangchonlatip, K., \& Punpuing, S. (2020). A confluence of worries: Grandparents in skippedgeneration households in Thailand. Journal of Family Issues, 41(2), 135-157.

33) Piotrowski, M. (2009). Migrant remittances and skipped generation households: Investigating the exchange motive using evidence from Nang Rong, Thailand. Asian and Pacific Migration Journal, 18(2), 163-196.

34) Tangchonlatip, K., Ingersoll-Dayton, B., \& Punpuing, S. (2021). Conflict in skipped generation households in Thailand. The International Journal of Aging and Human Development, 92(1), 3-21.

35) Silverstein, M., Cong, Z., \& Li, S. (2006). Intergenerational transfers and living arrangements of older people in rural China: Consequences for psychological well-being. The Journals of Gerontology Series B: Psychological Sciences and Social Sciences, 61(5), S256-S266.

36) Chen, F., \& Liu, G. (2012). The health implications of grandparents caring for grandchildren in China. Journals of Gerontology Series B: Psychological Sciences and Social Sciences, 67(1), 99-112. 